\title{
FORMATION OF VOLATILE ORGANIC COMPOUNDS AT THERMOOXIDATION OF SOLID FOSSIL FUELS
}

\author{
T. KALJUVEE* , E. EDRO, R. KUUSIK \\ Tallinn University of Technology, \\ Ehitajate tee 5, 19086 Tallinn, Estonia
}

\begin{abstract}
Thermoanalytical technique combined with FTIR equipment was used for comparative estimation of thermal behavior of samples with simultaneous identification of gaseous compounds formed and emitted at thermooxidation of solid fossil fuels (oil shale, semicoke, coal) from different deposits (Estonia, Israel, Jordan, Morocco, Bulgaria, Russia). The experiments were carried out under dynamic heating conditions up to $900{ }^{\circ} \mathrm{C}$ at heating rates of 5,10 or $50 \mathrm{~K} \mathrm{~min}^{-1}$ in a stream of dry air. In addition to $\mathrm{CO}_{2}$ and $\mathrm{H}_{2} \mathrm{O}$ as major gases evolved, a number of individual volatile species like $\mathrm{CO}, \mathrm{SO}_{2}$, COS, methane, ethane, ethylene, formaldehyde, acetaldehyde, formic acid, methanol, chlorobenzene, etc. were determined. Notable differences in the composition of gaseous compounds evolved as well as differences in the absorbance of individual species in FTIR spectra depending on the origin of fuel and on the heating rate used were determined.
\end{abstract}

\section{Introduction}

Combustion of solid fossil fuels in industrial boilers leads to the contamination of the atmosphere with different toxic and environmentally unfriendly compounds such as $\mathrm{CO}_{2}, \mathrm{CO}, \mathrm{SO}_{2}$, volatile organic compounds (VOCs), and polycyclic aromatic hydrocarbons (PHAs).

$60 \%$ of the total energy production in Estonia and $95 \%$ of the electricity production, which is concentrated into the Estonian and Baltic Power Plants, is based on combustion of Estonian oil shale (EOS). Up to 2004 these power plants operated on high-temperature $\left(1200-1400{ }^{\circ} \mathrm{C}\right)$ combustion of pulverized EOS only, but since 2004 the two energy blocks with circulating fluidized-bed combustion (CFBC) boilers $\left(780-820^{\circ} \mathrm{C}\right)$ have been implemented, this technology being more suitable for low-grade fuels. The data published in $[1,2]$ confirmed that the contamination of the atmosphere in Estonia with VOCs, including PHAs [3], formed at Narva power plants at high-temperature combustion of EOS is not very high - at the level of 200300 tons per year. It indicates that VOCs formed during incomplete firing of

\footnotetext{
* Correspondence author: e-mail tiidu@staff.ttu.ee
} 
EOS were decomposed and oxidized almost completely before leaving the boiler. However, when using FBC technique for combustion of solid fossil fuels, combustion temperature is much lower and the conditions for formation and preservation of VOCs are more suitable.

The use of TG-DTA technique combined with FTIR is an efficient tool for identification of gaseous compounds evolved at thermal treatment of fuels in neutral [4-7] as well as in oxygen [8,9] atmosphere. Earlier, an attempt for estimation of gaseous compounds evolved at thermooxidation of some oil shale samples was made [10]. The goal of the current research was a precise and comparative thermal characterization of low-grade oil shale and coal samples from different deposits (Estonia, Jordan, Israel, Morocco, Bulgaria, Russia) with identification of gaseous compounds formed and emitted, as well as the estimation of the influence of some additives $(\mathrm{CaO}$, $\mathrm{MgO}$, oil shale ash) as main specific compounds of the mineral part of lowgrade fuels on the composition and relationship between gaseous compounds evolved by using TG-FTIR technique.

\section{Materials and methods}

Two samples of EOS, one sample of Jordanian (JOS), Israeli (IOS) and Moroccan (MOS) oil shale, one sample of Estonian oil shale semicoke (SC), four samples of Bulgarian (B) and one sample of Russian (R) coal were studied.

Using different methods of chemical analyses, the chemical composition as well as the gross calorific (high heating) value (calorimeter B-08BM) of these samples was determined (Table 1). For elemental analysis (Vario EL analyzer) the previously air-dried and ground samples were supplementary dried at $105^{\circ} \mathrm{C}$ for 24 hours.

The content of organic matter and fixed carbon in the dry samples was calculated as:

$$
\left[100-\mathrm{A}^{\mathrm{d}}-\left(\mathrm{CO}_{2}\right)_{\mathrm{M}}{ }^{\mathrm{d}}\right], \%
$$

where $\mathrm{A}^{\mathrm{d}}$ is the content of ash, \%; $\left(\mathrm{CO}_{2}\right)_{\mathrm{M}}{ }^{\mathrm{d}}$ is the content of mineral carbon dioxide, $\%$, both on dry basis.

Oil shale samples studied are characterized by low content of organic matter - between 17-30\% - except EOS II (63\%) being almost pure kerogen and, respectively, by high content of mineral matter - 70-83\% (EOS II $37 \%$ ) (Table 1). The content of mineral $\mathrm{CO}_{2}$ indicated high content of carbonates - calcite, dolomite - in oil shale samples. On the contrary, the content of organic matter and fixed carbon in coal samples was between $82-89 \%$, except in two Bulgarian coal samples B2 and B4 being the tailings of enrichment - 60-65\%. Carbonates in coal samples studied were practically missing (Table 1 ). 
Table 1. Main characteristics of samples (on dry basis)

\begin{tabular}{|c|c|c|c|c|c|c|c|c|c|c|c|}
\hline $\begin{array}{c}\text { Content, } \\
\text { wt. } \%\end{array}$ & EOS I & EOS II & JOS & IOS & MOS & $\mathrm{SC}$ & B2 & B3 & B4 & B5 & $\mathrm{R} 12$ \\
\hline $\begin{array}{l}\text { Organic } \\
\text { matter + } \\
\text { fixed C }\end{array}$ & 29.7 & 63.1 & 22.6 & 17.1 & 18.5 & 13.1 & 59.4 & 82.1 & 64.1 & 82.8 & 88.5 \\
\hline Ash & 50.5 & 32.1 & 61.9 & 60.3 & 66.4 & 68.8 & 40.2 & 17.8 & 35.8 & 17.2 & 11.5 \\
\hline$\left(\mathrm{CO}_{2}\right)_{\mathrm{M}}$ & 19.8 & 5.8 & 15.5 & 22.6 & 15.1 & 18.1 & 0.4 & 0.1 & 0.1 & 0 & 0 \\
\hline $\mathrm{S}_{\text {total }}$ & 1.63 & 1.22 & 3.52 & 2.60 & 1.97 & 2.38 & 4.42 & 5.86 & 4.07 & 5.69 & 3.29 \\
\hline $\mathrm{S}_{\mathrm{pyr}}$ & 1.20 & 0.47 & 0.28 & 0.88 & 0.34 & 0.60 & 1.13 & 2.41 & 0.64 & 1.66 & 0 \\
\hline $\mathrm{S}_{\text {sulph }}$ & 0.10 & 0.04 & 0.12 & 0.32 & 0.10 & 0.44 & 1.43 & 0.26 & 2.42 & 0.27 & 0.66 \\
\hline $\mathrm{S}_{\text {org }}$ & 0.33 & 0.71 & 3.12 & 1.40 & 1.53 & 0.74 & 1.86 & 3.19 & 1.01 & 3.76 & 2.63 \\
\hline $\mathrm{S}_{\text {sulphide }}$ & 0 & 0 & 0 & 0 & 0 & 0.60 & 0 & 0 & 0 & 0 & 0 \\
\hline $\mathrm{N}$ & 0.53 & 0.09 & 0.42 & 0.39 & 0.50 & 0.52 & 0.47 & 0.60 & 0.42 & 0.59 & 1.37 \\
\hline $\mathrm{H}$ & 3.00 & 5.96 & 2.24 & 1.46 & 1.65 & 1.21 & 3.37 & 5.00 & 3.59 & 5.20 & 5.15 \\
\hline $\mathrm{C}$ & 28.3 & 48.5 & 22.2 & 17.1 & 16.3 & 17.9 & 34.9 & 54.2 & 35.2 & 54.6 & 67.7 \\
\hline$(\mathrm{C} / \mathrm{H})_{\text {total }}^{\text {mole }}$ & 1.27 & 1.47 & 1.21 & 1.02 & 1.21 & 0.81 & 1.16 & 1.11 & 1.14 & 1.14 & 0.91 \\
\hline $\begin{array}{l}\text { Gross } \\
\text { calorific } \\
\text { value, } \\
\mathrm{MJ} \mathrm{kg}^{-1}\end{array}$ & 10.24 & 22.43 & 8.14 & 4.90 & - & 4.12 & 16.80 & 23.18 & - & 23.09 & 29.82 \\
\hline
\end{tabular}

The samples studied were characterized by relatively high content of sulphur which in oil shale samples varied from $1.22 \%$ (EOS II) to $3.52 \%$ (JOS), and in coal samples from $3.29 \%$ (R12) to 5.86\% (B3) including at that pyritic, organic and sulphate sulphur, and in SC, additionally, also sulphide sulphur. The content of hydrogen varied in oil shale samples from $1.46 \%$ (IOS) to $5.96 \%$ (EOS II), and in coal samples from $3.37 \%$ (B2) to $5.20 \%$ (B5) (Table 1).

There were no significant differences observed in the mole ratio of $(\mathrm{H} / \mathrm{C})^{\text {total }}$ for oil shale (between 1.02 and 1.27, for EOS II - 1.47) and coal samples (between 1.11 and 1.22, and for R12 - 0.91) (Table 1). The mole ratio of $\mathrm{H} / \mathrm{C}^{\text {org }}$ calculated was much higher for oil shale samples - between 1.50 and 1.62 - than for coal samples (0.91-1.22) indicating that formation of VOCs at thermal treatment of oil shale samples is more probable than that in the case of coal samples.

\section{Methods}

The TG-FTIR system consisted of Setaram Labsys 2000 equipment coupled to the Interspec 2020 Fourier Transform Infrared Spectrometer by a transfer line. The Ranger-AlP Gas Cell, S/N 23790, (REFLEX Analytical Co) with $8.8 \mathrm{~m}$ path length and $\mathrm{KBr}$ windows was used. Both, the transfer line and the gas cell were heated to $150{ }^{\circ} \mathrm{C}$ to prevent condensation. The gas cell was equipped with DTSG (deuterated triglycine sulphate) detector cooled with liquid nitrogen. FTIR measurements were recorded in the $4000-600 \mathrm{~cm}^{-1}$ region with a resolution of $4 \mathrm{~cm}^{-1}$ and 4 scans as an average. The Bio- 
Rad (Sadtler) KnowItAll search program and Gases\&Vapours Database (code GS) and Organics \& Polymers Database (code TU, SR) were used.

The experiments were carried out under dynamic heating conditions up to $900{ }^{\circ} \mathrm{C}$ at heating rates of 5,10 or $50 \mathrm{~K}$ per minute in a stream of dry air $\left(70 \mathrm{~mL} \mathrm{~min}{ }^{-1}\right)$. In case of using the heating rate of $50{ }^{\circ} \mathrm{C} \mathrm{min}^{-1}$, the final temperature was held constant during 15 minutes. Setaram Labsys 2000 enabled simultaneous fixation of TG, DTG and DTA data. Standard $100 \mu \mathrm{L}$ Pt-crucibles were used; the mass of samples was 20-30 mg depending on the content of organic matter in the samples used. For modeling the CFBC process, the impact of $\mathrm{CaO}, \mathrm{MgO}$, and oil shale ash addition on the formation and emission of gaseous compounds was studied. The mole ratio of $\mathrm{CaO}(\mathrm{MgO}) /(\mathrm{S}+\mathrm{Cl})^{\text {fuel }}$ or, in the case of using ash $\mathrm{CaO}_{\text {free }} /(\mathrm{S}+\mathrm{Cl})^{\text {fuel }}$, was 2.0. The reactive grade of $\mathrm{CaO}$ and $\mathrm{MgO}$ (VWR International Ltd.) and bottom ash from pulverized EOS combustion at Estonian PP were used. The content of the total $\mathrm{CaO}$ and free $\mathrm{CaO}$ in the ash used was $50.8 \%$ and $23.0 \%$, respectively.

\section{Results and discussion}

\section{Thermal analyses}

Thermooxidation of oil shale and semicoke samples proceeded in three steps. Firstly, thermooxidation of volatile organic compounds, secondly, thermooxidation of the heavier part of organic matter (kerogen) and fixed carbon, as well as thermooxidation of pyrite and, finally, decomposition of carbonates $[8,10-16]$. For coal samples, the last step was not observed because the content of carbonates in coal samples was negligible or nil (Table 1).

At the heating rates of 5 and $10{ }^{\circ} \mathrm{C} \mathrm{min}^{-1}$, the emission of adsorbed water and gaseous species proceeded up to $150-180{ }^{\circ} \mathrm{C}$, and the mass loss at that was for oil shale and coal samples in the range of $0.9-2.5 \%$ (Fig. $1 a$ ) and $2-10 \%$ (Fig. 1b), respectively. At the heating rate of $50^{\circ} \mathrm{min}^{-1}$ it continued up to $200-230{ }^{\circ} \mathrm{C}$ with the mass loss of $1-8.5 \%$ (Fig. 2). The first step of thermooxidation of organic matter for oil shale samples lasted, depending on the origin of the sample, up to $375-450{ }^{\circ} \mathrm{C}$ (Fig. $1 a, 3 a$ and $3 b$ ), but for coal samples up to $300-380{ }^{\circ} \mathrm{C}$ only (Fig. $1 b, 4 a$ and $4 b$ ) indicating the differences in the composition of organic matter of oil shale and coal samples, and being the lowest among oil shale and coal samples for JOS and $\mathrm{B} 2$, respectively, and the highest for EOS II and R12. The second step of thermooxidation of organic matter for oil shale samples lasted up to 520 $565^{\circ} \mathrm{C}$ and for EOS II, rich in kerogen, even up to $685^{\circ} \mathrm{C}$ (Fig. $3 b$ ). For coal samples it continued up to $450-630{ }^{\circ} \mathrm{C}$, being the lowest for $\mathrm{B} 2$ and the highest for R12. However, the boundary between the first and second steps of thermooxidation of organic matter could not be always clearly defined, as it depends very much on the origin of the sample and the heating rate used, being quite similar to the results presented in $[12,13]$. 


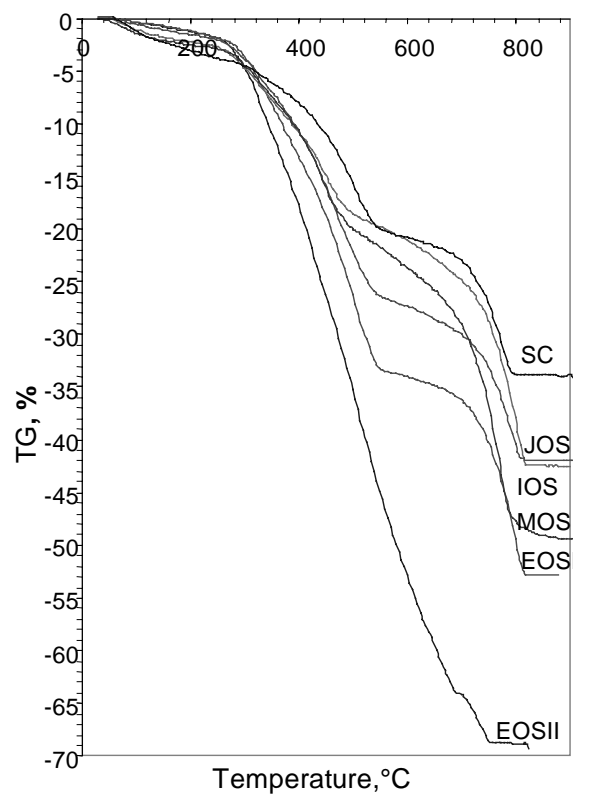

Fig. 1a. TG curves of oil shale and semicoke samples thermooxidated at a heating rate of $10^{\circ} \mathrm{C} \mathrm{min}^{-1}$.

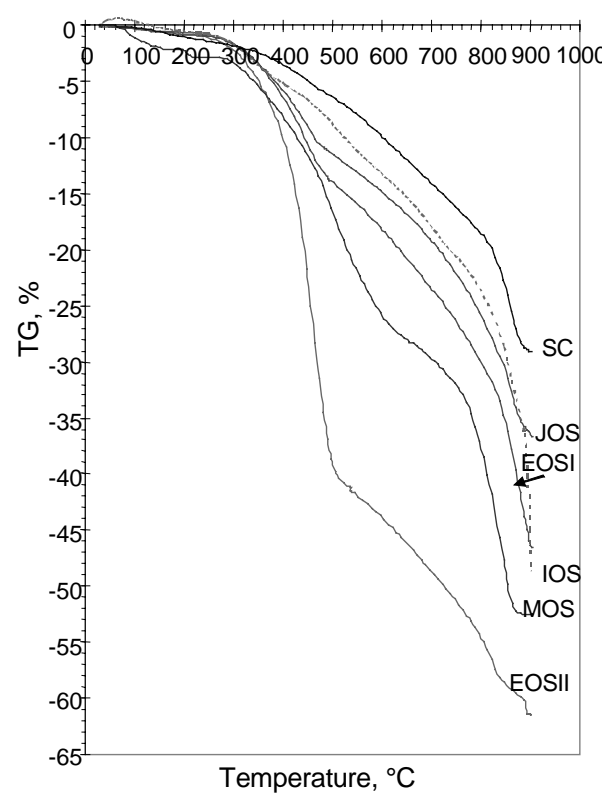

Fig. 2a. TG curves of oil shale and semicoke samples thermooxidated at a heating rate of $50{ }^{\circ} \mathrm{C} \mathrm{min}$.

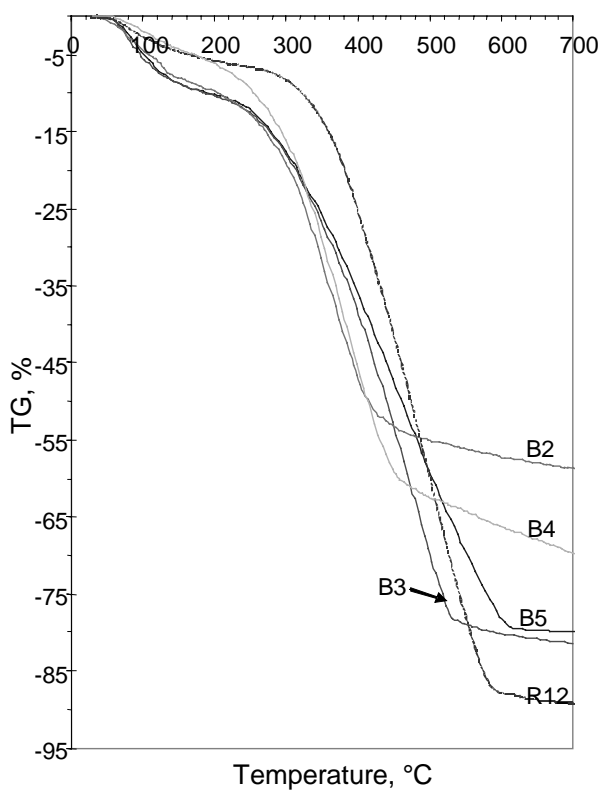

Fig. 1 b. TG curves of coal samples thermooxidated at a heating rate of $10{ }^{\circ} \mathrm{C} \min ^{-1}$.

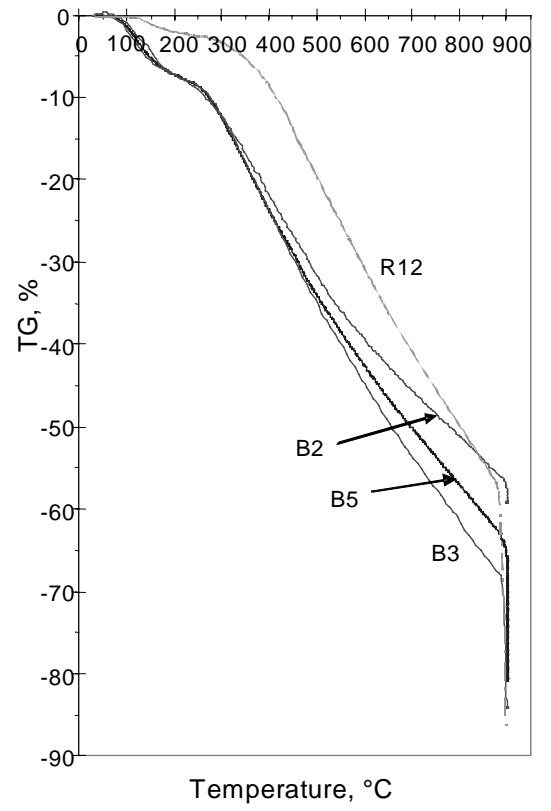

Fig. 2b. TG curves of coal samples thermooxidated at a heating rate of $50{ }^{\circ} \mathrm{C} \mathrm{min}{ }^{-1}$. 
The total mass loss considering both steps of thermooxidation was $16.6 \%$ for SC, 20.5-63.5\% for oil shale samples, being definitely the highest for EOS II, and $60-88 \%$ for coal samples, being the lowest for B2 and the highest for R12.

The third step of thermooxidation of OS and SC samples is mainly related to decomposition of carbonates, which can be followed by the endoeffect in DTA curves with the minimum at $720-808^{\circ} \mathrm{C}$ (Fig. $3 a$ and $3 b$ ). The mass loss was completed at $740-820{ }^{\circ} \mathrm{C}$, and the total mass loss at that varied between $33.9 \%$ (SC) and $68.5 \%$ (EOS II). The total mass loss for coal samples heated up to $900{ }^{\circ} \mathrm{C}$ varied from $60 \%$ (B2) to $89 \%$ (R12).

The peaks in DTA curves of EOS II at $302{ }^{\circ} \mathrm{C}, 352{ }^{\circ} \mathrm{C}, 483{ }^{\circ} \mathrm{C}$ (Fig. $3 a$ ) and at $348{ }^{\circ} \mathrm{C}, 409{ }^{\circ} \mathrm{C}, 588^{\circ} \mathrm{C}$ (Fig. $3 b$ ) heated up at the heating rate of $5{ }^{\circ} \mathrm{C}$ and $10{ }^{\circ} \mathrm{C} \mathrm{m^{-1 }}$, respectively, as well as peaks in DTA curves of B3 at $338^{\circ}, 457^{\circ}$, a shoulder at $419^{\circ} \mathrm{C}\left(5^{\circ} \mathrm{C} \mathrm{min}-1\right)$ (Fig. $\left.4 a\right)$, and a peak at $498{ }^{\circ} \mathrm{C}$, a shoulder at $369^{\circ} \mathrm{C}\left(10^{\circ} \mathrm{C} \mathrm{min}^{-1}\right)$ (Fig. $\left.4 b\right)$ demonstrate well the complexity of decomposition of organic matter (kerogen). The extremely complicated chemical composition of kerogen in EOS is well proved in [17].

At the heating rate of $50{ }^{\circ} \mathrm{C} \mathrm{min}^{-1}$, the first and the second steps of thermooxidation were better differentiated for the samples in which organic matter contains more volatile compounds - Estonian OS, Jordanian OS and Bulgarian coal samples Nos 3 and 5 (Table 1). For example, the maxima of exoeffects in DTA curves at $346^{\circ}, 522^{\circ}$, and $630^{\circ}$ for EOS II and at $371^{\circ}$ and $470^{\circ}$ for $\mathrm{B} 3$ are clearly separated by a deep minimum between them at $497^{\circ}$ and $535^{\circ} \mathrm{C}$ for EOS II (Fig. 3c) and at $397^{\circ} \mathrm{C}$ for B3 (Fig. $4 c$ ). The peak maxima at $522{ }^{\circ} \mathrm{C}$ in the DTA curve of EOS II corresponds to thermooxidation of pyrite. The peak maxima in DTA and DTG curves as well as the boundary between the first and the second steps of thermooxidation were shifted towards higher temperatures by $50-90{ }^{\circ} \mathrm{C}$ compared to lower heating rate (Figures 1-4) being at that in a good correlation with the results published in $[6,9,18]$. For R12, the exoeffect in the DTA curve was presented only as one big massive with mini maximums and shoulders. However, it was not possible clearly to differentiate the second and the third steps in OS samples resulting from incomplete thermooxidation of the heavier part of kerogen before beginning of decomposition of carbonates at the higher heating rate. The mass loss was completed after two (B2) to twelve (EOS II) minutes of holding the samples at $900{ }^{\circ} \mathrm{C}$ (Figures $3 \mathrm{C}$ and $4 \mathrm{C}$ ). At that the total mass loss for oil shale samples was $4-5 \%$ and for coal samples $1-3 \%$ smaller than at low heating rates (Figures 1-2), which could have been caused by incomplete changes within the mineral part of samples or/and partial binding of gaseous species $\left(\mathrm{SO}_{2}, \mathrm{CO}_{2}, \mathrm{HCl}\right)$ formed and evolved during thermooxidation of the samples, for example, by free $\mathrm{Ca}, \mathrm{Mg}$-oxides formed during decomposition of carbonates or by silicates [19-24]. 


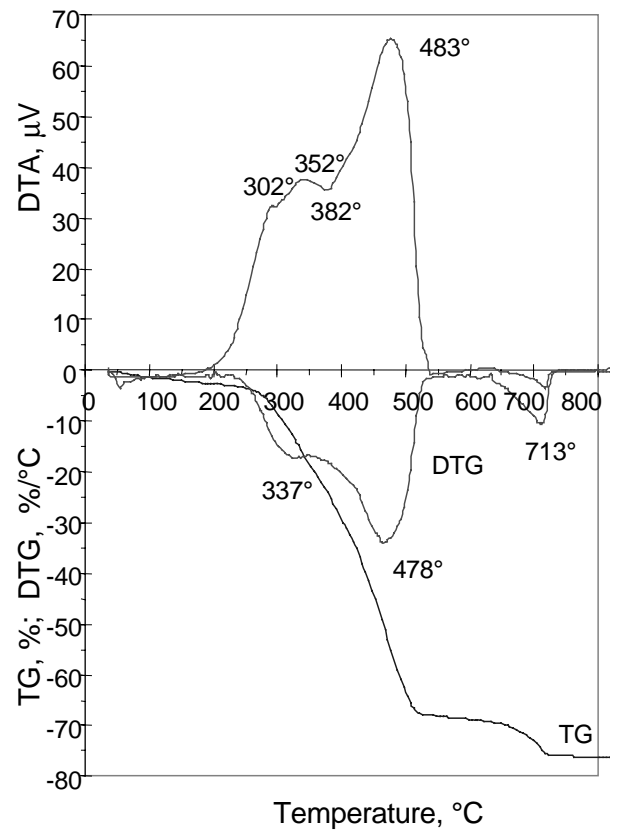

Fig. 3a. Thermal curves of EOS II thermooxidated at a heating rate of $5{ }^{\circ} \mathrm{C} \mathrm{min}^{-1}$.

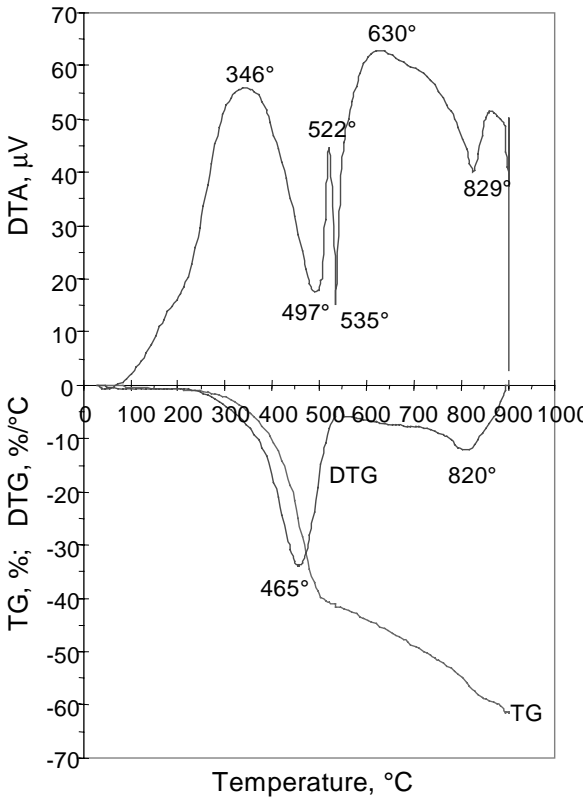

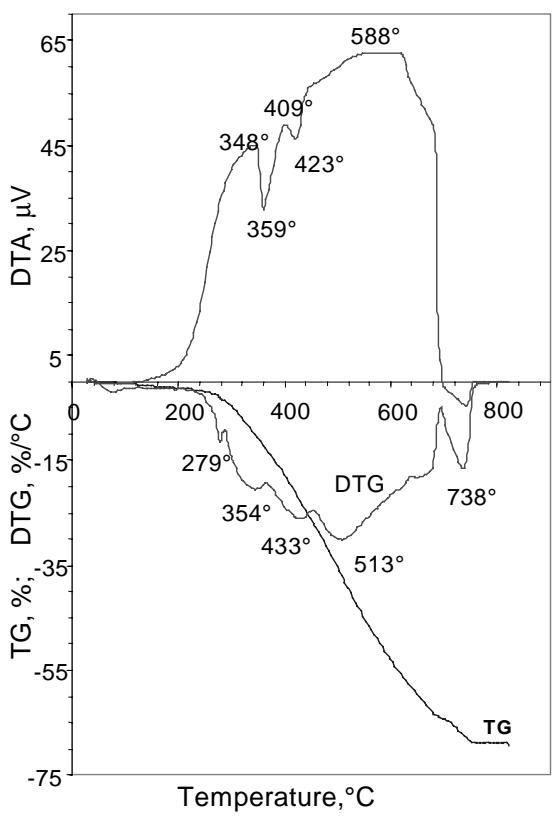

Fig. 3b. Thermal curves of EOS II thermooxidated at a heating rate of $10{ }^{\circ} \mathrm{C} \mathrm{min}{ }^{-1}$.
Fig. 3c. Thermal curves of EOS II thermooxidated at a heating rate of $50{ }^{\circ} \mathrm{C} \min ^{-1}$. 


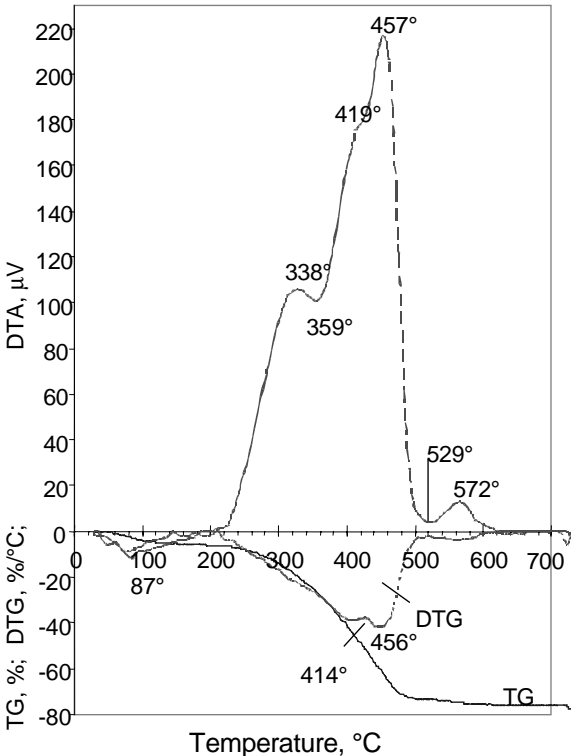

Fig. 4a. Thermal curves of B3 thermooxidated at a heating rate of $5^{\circ} \mathrm{C} \mathrm{min}^{-1}$.

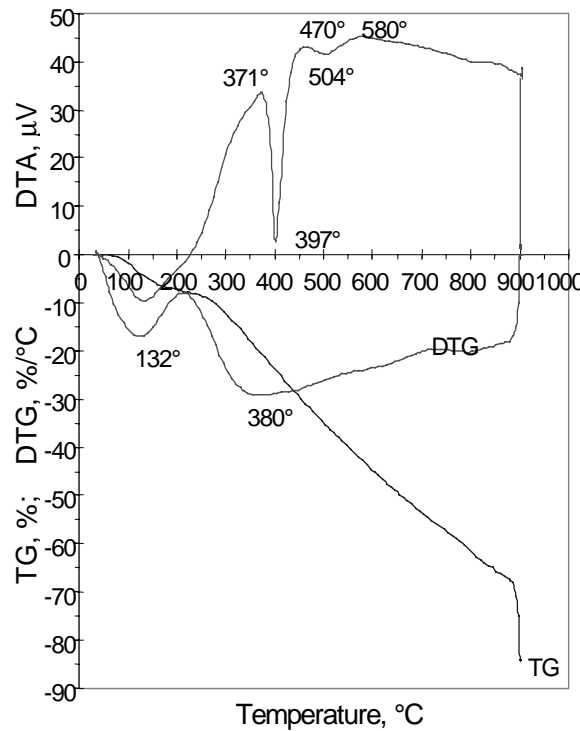

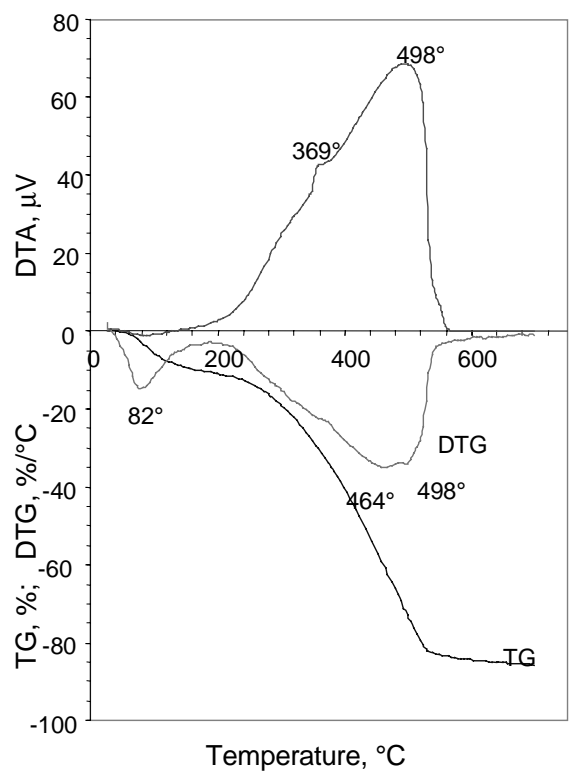

Fig. 4b. Thermal curves of B3 thermooxidated at a heating rate of $10{ }^{\circ} \mathrm{C} \mathrm{min}^{-1}$.
Fig. 4c. Thermal curves of $\mathrm{B} 3$ thermooxidated at a heating rate of $50{ }^{\circ} \mathrm{C} \mathrm{min}$. 


\section{FTIR analyses}

The list of gaseous compounds evolved at thermooxidation of solid fossil fuels studied differed lightly from each other depending on the origin of fuel. More differences were observed in the intensities of characteristic peaks of different species evolved in FTIR spectra depending on the origin of fuel as well as on the heating rate of thermooxidation which were in a good correlation with the results described earlier in [8-10].

A part of FTIR spectra of gaseous compounds evolved at different temperatures during the TG scan of fuel samples studied at heating rate of $10{ }^{\circ} \mathrm{C} \mathrm{min}{ }^{-1}$ is presented in Figures 5-8. The two major gaseous compounds evolved at thermooxidation of fuels were $\mathrm{CO}_{2}$ and $\mathrm{H}_{2} \mathrm{O}$. The appearance of characteristic water bands in FTIR spectra in broad ranges $3900-3500 \mathrm{~cm}^{-1}$ and $1900-1300 \mathrm{~cm}^{-1}$ and the characteristic peaks for $\mathrm{CO}_{2}(2380$ and $678 \mathrm{~cm}^{-1}$ ) below $180-200{ }^{\circ} \mathrm{C}$ indicated the emission of water and carbon dioxide adsorbed in the samples. The presence of water absorption bands in these ranges causes the overlapping of characteristic peaks of other gas species at higher temperatures complicating at that the identification of them.

In addition to $\mathrm{CO}_{2}$ and water, the characteristic peaks for $\mathrm{CO}(2178$ and $\left.2113 \mathrm{~cm}^{-1}\right)$, acetic $\left(1798\right.$ and $\left.1176 \mathrm{~cm}^{-1}\right)$ and formic $\left(1749\right.$ and $\left.1108 \mathrm{~cm}^{-1}\right)$ acids, formaldehyde (1749 and $\left.1706 \mathrm{~cm}^{-1}\right)$ and acetaldehyde (1763 and $\left.1420 \mathrm{~cm}^{-1}\right)$, ketons $\left(1719 \mathrm{~cm}^{-1}\right), \mathrm{SO}_{2}\left(1375\right.$ and $\left.1362 \mathrm{~cm}^{-1}\right)$, ethane $(2970$ and $\left.1458 \mathrm{~cm}^{-1}\right)$ and chlorobenzene $\left(1473 \mathrm{~cm}^{-1}\right.$ and $\left.742 \mathrm{~cm}^{-1}\right)$ were clearly fixed in FTIR spectra of all the samples studied (Figures 5-8).

The characteristic peaks for methane (3016 and $1307 \mathrm{~cm}^{-1}$ ), $\mathrm{HCl}$ (absorption bands in broad ranges 3000-2700 $\left.\mathrm{cm}^{-1}\right)$, COS $\left(2074\right.$ and $\left.2052 \mathrm{~cm}^{-1}\right)$, methanol (1034 and $\left.1008 \mathrm{~cm}^{-1}\right)$, ethanol $\left(1244\right.$ and $\left.1052 \mathrm{~cm}^{-1}\right)$, ethylene $\left(1648 \mathrm{~cm}^{-1}\right.$ and $\left.950 \mathrm{~cm}^{-1}\right), p$-xylene $\left(1512\right.$ and $\left.793 \mathrm{~cm}^{-1}\right), \mathrm{NH}_{3}(967$ and $\left.933 \mathrm{~cm}^{-1}\right)$, and possibly furan $\left(746 \mathrm{~cm}^{-1}\right)$ were identified also in FTIR spectra of most of samples (Figures 5-8). The emission of $\mathrm{HCl}$ at thermooxidation of fuel samples was proved by appearing of characteristic absorption bands at $240-330{ }^{\circ} \mathrm{C}$ at $3000-2700 \mathrm{~cm}^{-1}$, which at higher temperatures could be overlapped (or disappeared) with more intensive bands of other compounds evolved.

Comparing the FTIR spectra of different samples it can be observed that these of IOS and MOS (Fig. 6), SC and R12 (Fig. 8) were a little bit poorer, and the characteristic peaks for many organic compounds in the FTIR spectra were usually less intensive than these for the other samples (Figures 5 and 7). At that the characteristic peaks for ethylene, methanol, and ethanol in the FTIR spectra of IOS and MOS (Fig. 6), methanol and ethanol in the FTIR spectra of R12 (Fig. 8) as well as these for ethylene, COS, p-xylene and methane in FTIR spectra of SC and for ethylene even in FTIR spectra of B4 were presented as traces. The characteristic peaks for methanol and ethanol in FTIR spectra of SC as well as these for $\mathrm{NH}_{3}$ in FTIR spectra of MOS (Fig. 6) were absent at all. These differences in the intensities of characteristic peaks of different compounds evolved at thermooxidation of 
samples in FTIR spectra could be explained by the differences in the content of organic matter, especially by the differences in elemental composition of samples (Table 1).

\section{The influence of heating rate}

The beginning of emission of most gaseous compounds formed at thermooxidation of the samples studied at heating rates of 5 and $10{ }^{\circ} \mathrm{C} \mathrm{min}{ }^{-1}$ was fixed in the interval of $180-250^{\circ} \mathrm{C}$, but some of them like $p$-xylene and chlorobenzene at $250-300{ }^{\circ} \mathrm{C}$ (Figures 5-8).

At the heating rate $5{ }^{\circ} \mathrm{C} \mathrm{min}{ }^{-1}$ the temperature of maximum intensities of characteristic peaks of COS, ethane and methane was $300-350{ }^{\circ} \mathrm{C}$ (Fig. 9), of ethylene, ethanol, formaldehyde, and formic acid $350-400{ }^{\circ} \mathrm{C}$ (Fig. 10), of $\mathrm{CO}$, acetic acid and acetaldehyde $400-450{ }^{\circ} \mathrm{C}$ and of $\mathrm{SO}_{2}, p$-xylene, and chlorobenzene $450-500{ }^{\circ} \mathrm{C}$ (Fig. 11).

At $10{ }^{\circ} \mathrm{C} \mathrm{min}^{-1}$, the temperature of maximum intensities of characteristic peaks of $\mathrm{COS}$ and ethane was $350^{\circ} \mathrm{C}$, that of $\mathrm{CO}$, ethanol, formaldehyde, methane and formic acid $400-450{ }^{\circ} \mathrm{C}$, of ethylene, acetaldehyde and acetic acid $450^{\circ} \mathrm{C}$ and of $\mathrm{SO}_{2}, p$-xylene and chlorobenzene $500-550{ }^{\circ} \mathrm{C}$, the temperatures being shifted by $50-150{ }^{\circ} \mathrm{C}$ towards higher temperatures as compared to these at the heating rate of $5^{\circ} \mathrm{C} \mathrm{min}^{-1}$ (Figures 9-11).

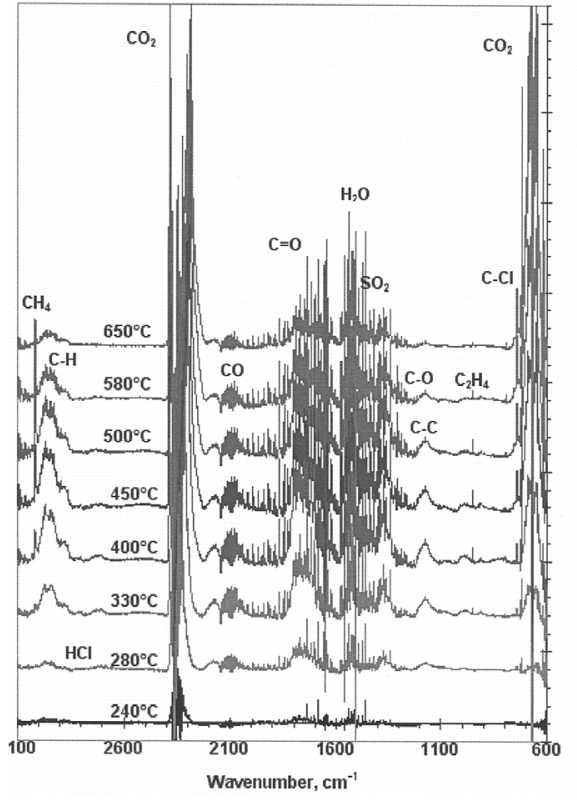

Fig. 5. FTIR spectra of gaseous compounds evolved at thermooxidation of EOS II $\left(10^{\circ} \mathrm{C} \mathrm{min}^{-1}\right)$.

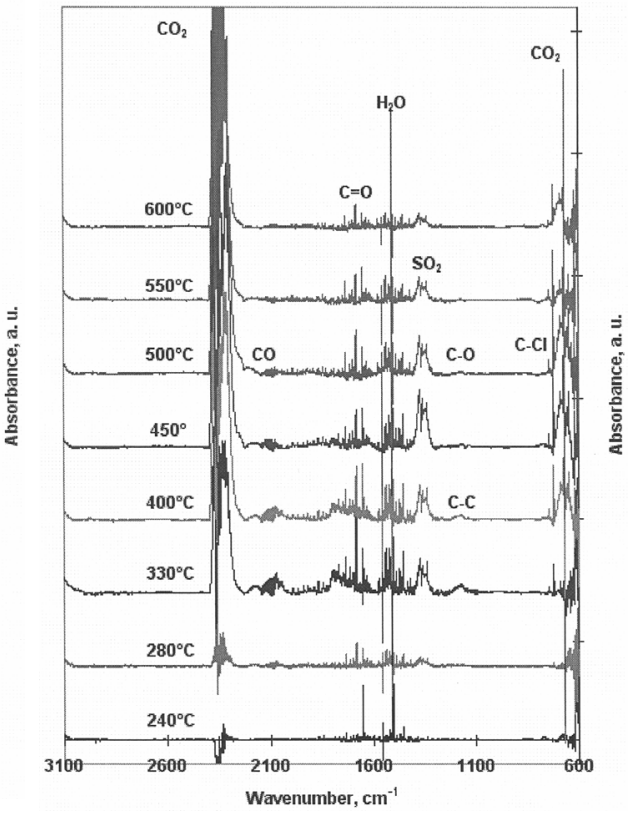

Fig. 6. FTIR spectra of gaseous compounds evolved at thermooxidation of $\operatorname{MOS}\left(10^{\circ} \mathrm{C} \mathrm{min}^{-1}\right)$. 


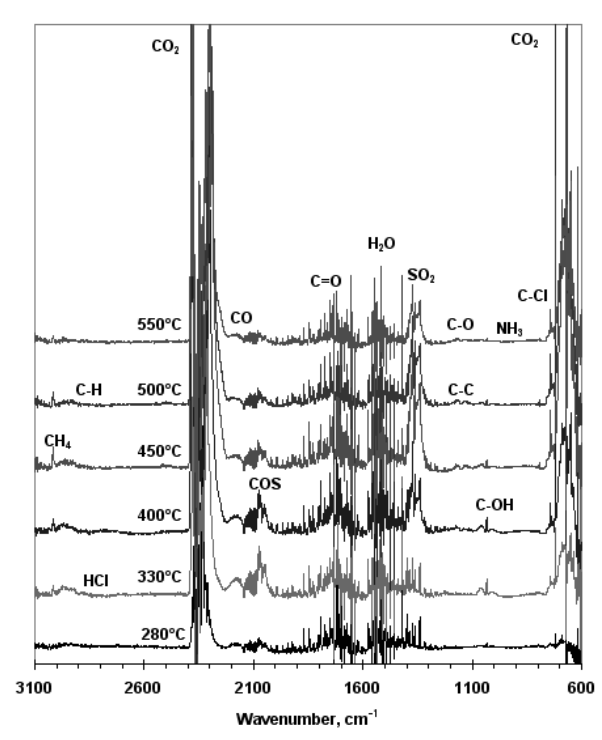

Fig. 7. FTIR spectra of gaseous compounds evolved at thermooxidation of Bulgarian coal No $3\left(10^{\circ} \mathrm{C} \min ^{-1}\right)$.

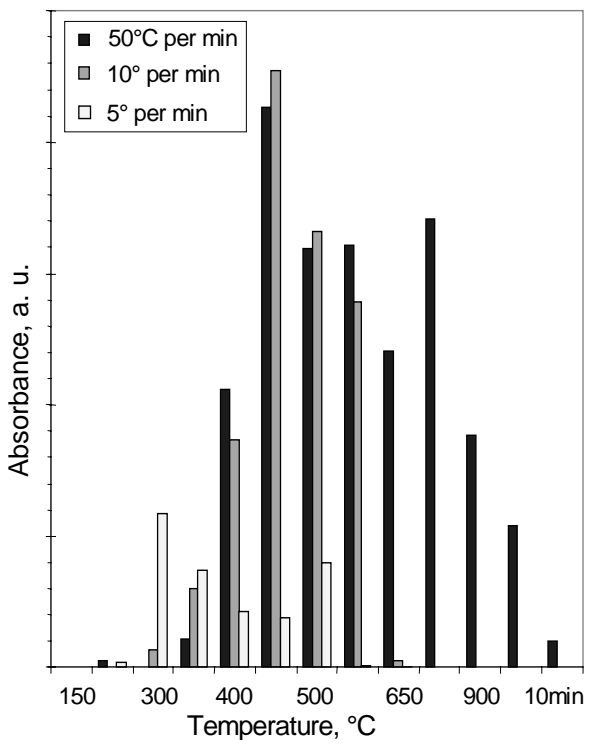

Fig. 9a. Absorbance profiles of methane evolved at thermooxidation of EOS II at different temperatures.

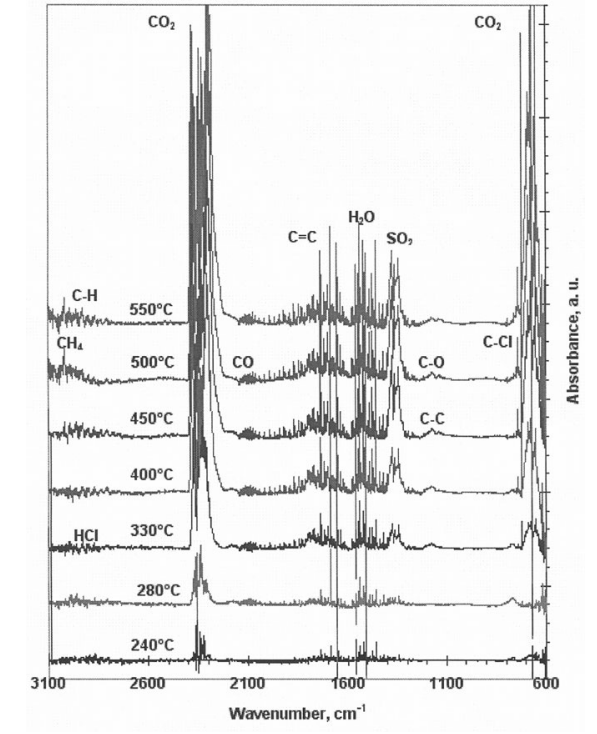

Fig. 8. FTIR spectra of gaseous compounds evolved at thermooxidation of Russian coal No $12\left(10{ }^{\circ} \mathrm{C} \mathrm{min}^{-1}\right)$.

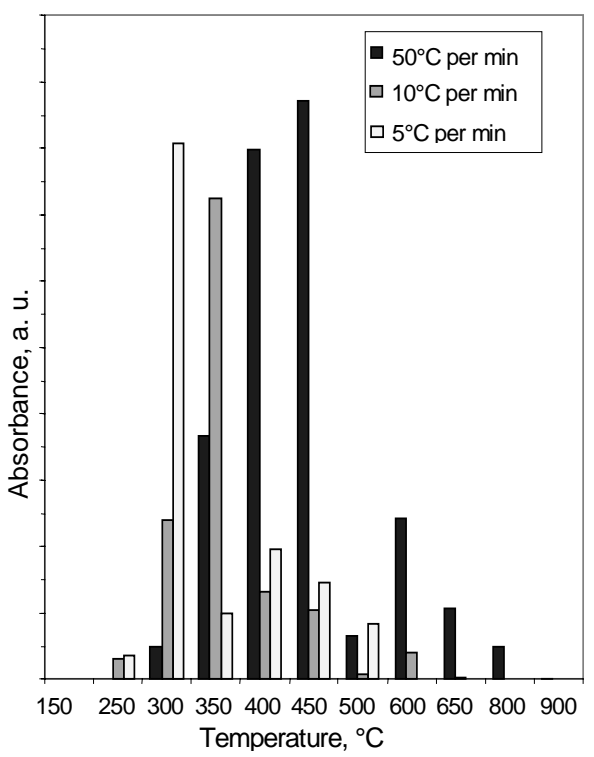

Fig. 9b. Absorbance profiles of ethane evolved at thermooxidation of IOS at different temperatures. 


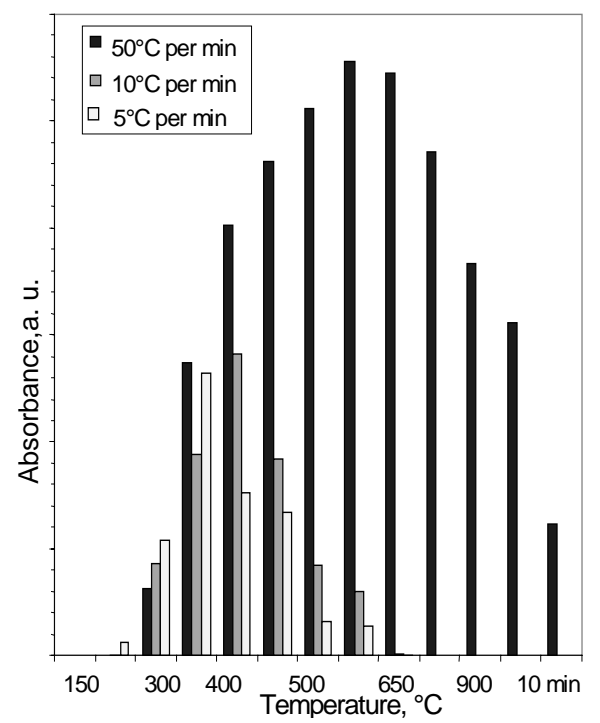

Fig. 10. Absorbance profiles of formic acid evolved at thermooxidation of JOS at different temperatures.

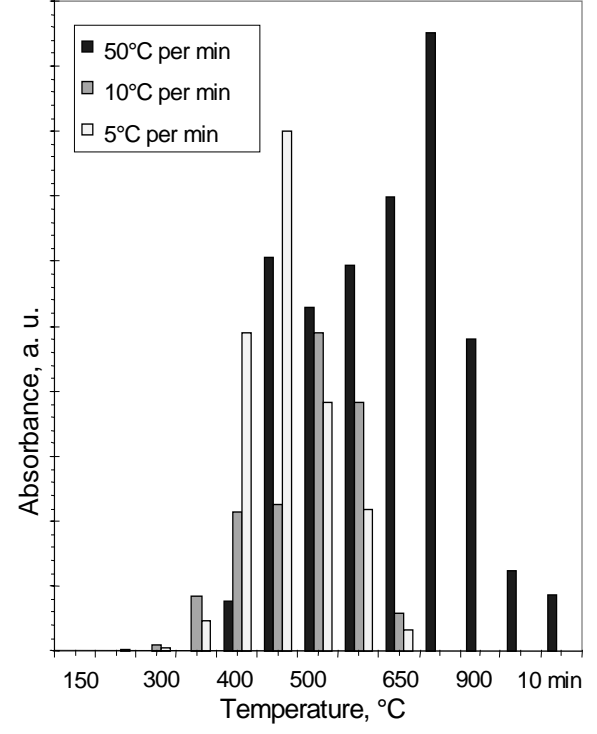

Fig. 11a. Absorbance profiles of p-xylene evolved at thermooxidation of EOS I at different temperatures.

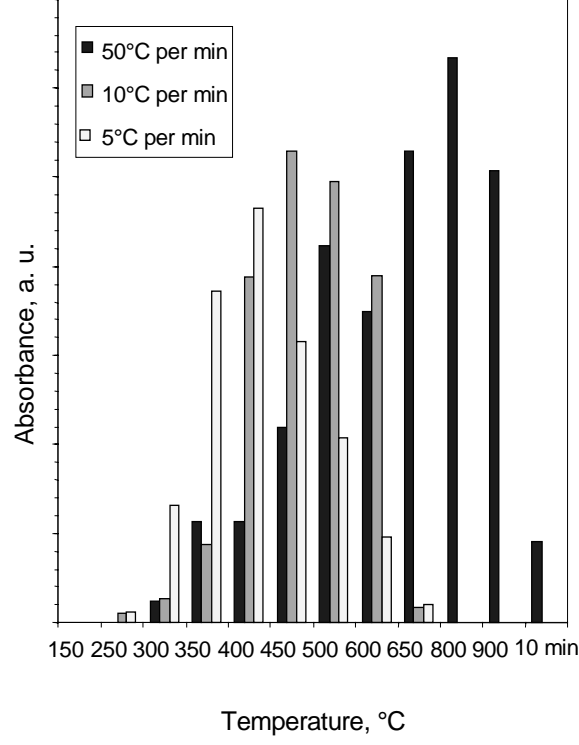

Fig. 11b. Absorbance profiles of chlorobenzene evolved at thermooxidation of B2 at different temperatures. 
During thermooxidation of coal and Jordanian oil shale samples at heating rates 5 and $10^{\circ} \mathrm{C} \mathrm{min}^{-1}$ the emission of methanol occurred in one step with maximum intensity in FTIR spectra at $350^{\circ}$ and $400{ }^{\circ} \mathrm{C}$, respectively, and in the case of the other oil shale samples in two steps with maximums at $300-350{ }^{\circ} \mathrm{C}$ and $450-500{ }^{\circ} \mathrm{C}$, respectively .

At the heating rate of $50{ }^{\circ} \mathrm{C} \mathrm{min}^{-1}$ the emission of the most of gaseous compounds formed started at $250-300{ }^{\circ} \mathrm{C}$, and that of $p$-xylene and chlorobenzene at $350-400{ }^{\circ} \mathrm{C}$ being shifted by $50-70{ }^{\circ} \mathrm{C}$ towards higher temperatures as compared to lower heating rates. At that the most of gaseous compounds evolved in two steps. The temperatures of maximum intensities of characteristic peaks of COS, CO, methane, ethane, methanol, and ethanol were $400-500{ }^{\circ} \mathrm{C}$ and $650-800{ }^{\circ} \mathrm{C}$, those of formic and acetic acid, formand acetaldehyde $-600-700{ }^{\circ} \mathrm{C}$, of two ethylene peaks $-450-500{ }^{\circ} \mathrm{C}$ and $700-800{ }^{\circ} \mathrm{C}$, of $\mathrm{SO}_{2}, p$-xylene and chlorobenzene $-450-600{ }^{\circ} \mathrm{C}$ and 800 $900{ }^{\circ} \mathrm{C}$ (Figures 9-11). So, the temperatures of maximum intensities of characteristic peaks were shifted towards higher temperatures by $70-300{ }^{\circ} \mathrm{C}$ and $150-450{ }^{\circ} \mathrm{C}$ as compared to heating rates of 10 and $5{ }^{\circ} \mathrm{C} \mathrm{min}{ }^{-1}$, respectively, and for most of the species evolved, the intensities of respective absorption bands increased together with the increase in the heating rate (Figures 9-11). It could be caused by the circumstance that at higher heating rates the contact-time between organic gaseous compounds formed at thermooxidation of solid fossil fuels and oxygen shortens and is not enough for complete oxidation of these species before they leave the furnace.

\section{The influence of lime-containing additives}

All the lime-containing materials used in our experiments had a great influence not only on the intensities of absorption bands of acidic gaseous compounds like sulphur dioxide and hydrogen chloride in FTIR spectra being in good correlation with the results obtained in [22, 25-26], but also on the intensities of carbonyl sulphide and chlorobenzene. The intensities of characteristic peaks for these compounds decreased, depending on the oil shale sample used and the gaseous compound evolved, 2-5 times (Figures 12-14), which means that a great part of $\mathrm{SO}_{2}$ and $\mathrm{HCl}$ formed during thermooxidation of fuels could be immediately bound into the solid phase by lime-containing material added, and the formation and emission of $\mathrm{COS}$ and chlorobenzene into the gaseous phase could be at that limited as well.

So, the use of CFBC technique for co-combustion of solid fossil fuels with lime-containing additives as sorbents for binding acidic gases (or formation of $\mathrm{Ca}, \mathrm{Mg}$-oxides at combustion of oil shale samples after decomposition of carbonates) enables to limit the contamination of the atmosphere with acidic gaseous compounds as well as with different VOCs. 


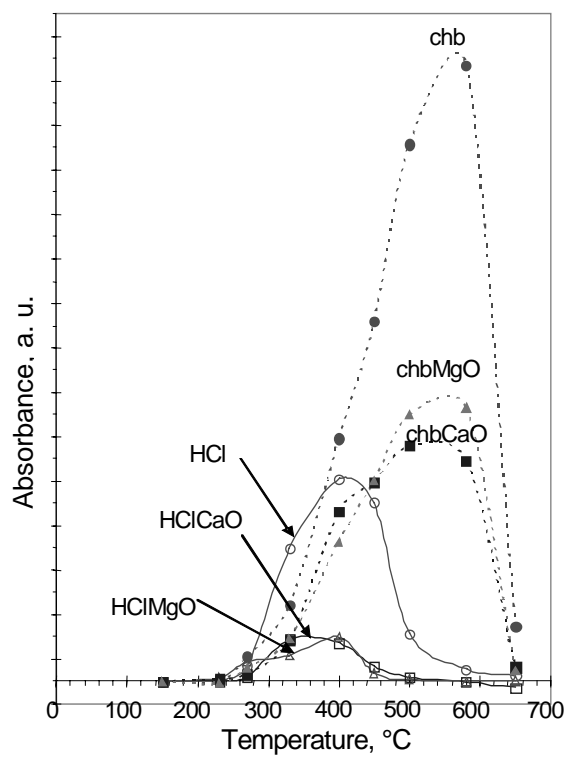

Fig. 12. Absorbance profiles of $\mathrm{HCl}$ and chlorobenzene evolved at thermooxidation of EOS I and its blends with $\mathrm{CaO}$ and $\mathrm{MgO}\left(10{ }^{\circ} \mathrm{C} \mathrm{min}^{-1}\right)$.

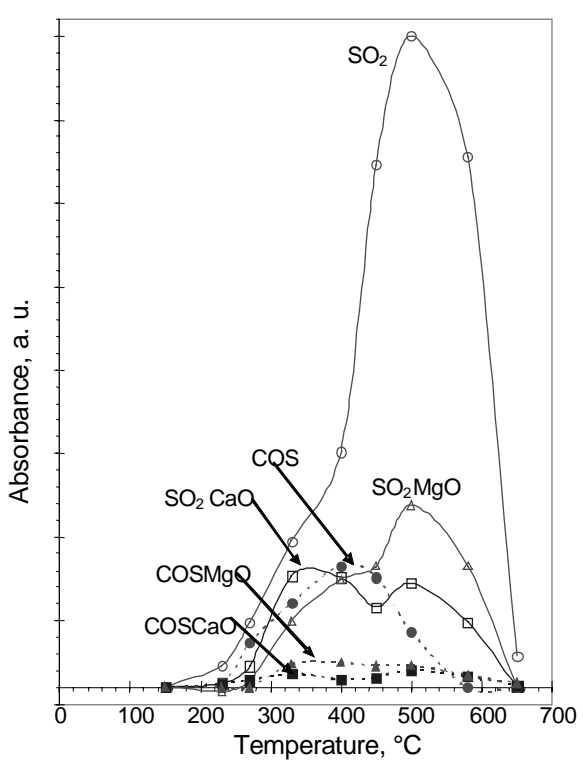

Fig. 13. Absorbance profiles of $\mathrm{SO}_{2}$ and $\mathrm{COS}$ evolved at thermooxidation of EOS I and its blends with $\mathrm{CaO}$ and $\mathrm{MgO}$ $\left(10{ }^{\circ} \mathrm{C} \mathrm{min}^{-1}\right)$.

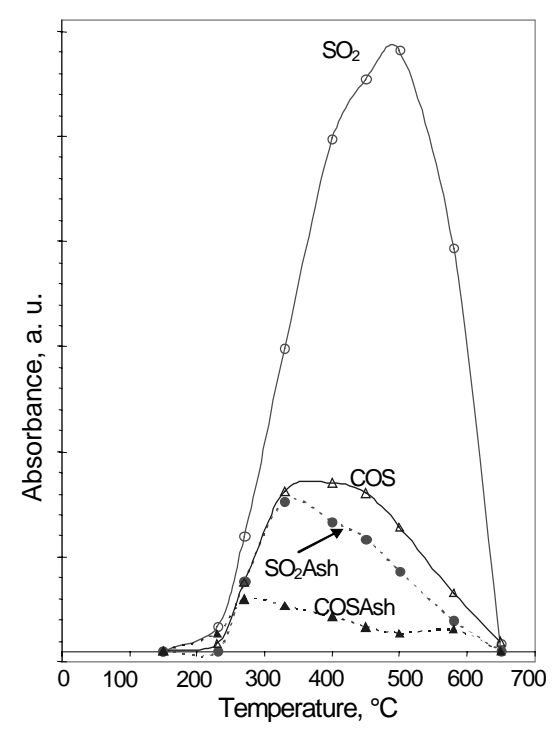

Fig. 14. Absorbance profiles of $\mathrm{SO}_{2}$ and $\mathrm{COS}$ evolved at thermooxidation of EOS II and its blends with oil shale $\operatorname{ash}\left(10^{\circ} \mathrm{C} \mathrm{min}^{-1}\right)$. 


\section{Conclusions}

The use of TA technique coupled with FTIR measurement enabled not only to determine the differences in thermal behavior of samples, but also to identify a number of individual volatile species formed and emitted at thermooxidation of solid fossil fuels. The differences in the composition of gaseous compounds evolved depending on the origin of fuels and on the heating rate were fixed.

Thermooxidation of oil shale and semicoke samples proceeded in three steps, that of coal samples in two steps.

The beginning of emission of most gaseous compounds formed at thermooxidation of samples studied at heating rates of 5 and $10^{\circ} \mathrm{C} \mathrm{min}^{-1}$ was fixed in the interval of $180-250{ }^{\circ} \mathrm{C}$, but for some of them like $p$-xylene and chlorobenzene at $250-300^{\circ} \mathrm{C}$. At the heating rate of $50{ }^{\circ} \mathrm{C} \mathrm{min}{ }^{-1}$, the emission of the most of gaseous compounds formed started at $250-300{ }^{\circ} \mathrm{C}$, that of $p$-xylene and chlorobenzene at $350-400{ }^{\circ} \mathrm{C}$, being shifted towards higher temperatures by $50-70{ }^{\circ} \mathrm{C}$ as compared to lower heating rates.

At the heating rate $5{ }^{\circ} \mathrm{C} \mathrm{min}{ }^{-1}$ the temperature of maximum intensities of characteristic peaks of COS, ethane, and methane was $300-350{ }^{\circ} \mathrm{C}$, that of ethylene, ethanol, $\mathrm{NH}_{3}$, formaldehyde, and formic acid $350-400{ }^{\circ} \mathrm{C}$, of $\mathrm{CO}$, acetic acid and acetaldehyde $400-450{ }^{\circ} \mathrm{C}$ and of $\mathrm{SO}_{2}, p$-xylene and chlorobenzene $450-500{ }^{\circ} \mathrm{C}$ being, as a rule, more intensive for oil shale samples. Thus, a good correlation between the absorbance of bands characteristic to VOCs evolved and the elemental composition of the samples was established.

At 10 and $50{ }^{\circ} \mathrm{C} \mathrm{min}^{-1}$, the temperatures of maximum intensities of characteristic peaks of different gaseous species evolved were shifted towards higher temperatures by $50-150{ }^{\circ} \mathrm{C}$ and $150-450{ }^{\circ} \mathrm{C}$, respectively, as compared to these at the heating rate of $5{ }^{\circ} \mathrm{C} \mathrm{min}^{-1}$, and for most of the species evolved, the intensities of respective absorption bands increased together with the increase in heating rate.

The lime-containing additives used in our experiments had a great influence on the intensities of absorption bands of acidic gaseous compounds like sulphur dioxide and hydrogen chloride in FTIR spectra, as well as on the intensities of carbonyl sulphide and chlorobenzene. Therefore, the CFBC technique for combustion of oil shale or the other solid fossil fuels with lime-containing additives could be an excellent tool for limiting the atmospheric contamination with acidic gaseous compounds as well as with VOCs.

\section{Acknowledgements}

This work was partly supported by the Estonian Science Foundation (Grant No. 5606). 


\section{REFERENCES}

1. Lahtvee, V. Energy and Environment. Estonian Energy 1999. Ministry of Economic Affairs. Tallinn, 2000. P. 52-59.

2. The state of Estonia's environment on the threshold of the 21st century. Information and Technological Center of the Ministry of Environment. Tallinn, 2000. 96 pp [in Estonian].

3. Ots, A. Formation of air-polluting compounds while burning oil shale // Oil Shale. 1992. Vol. 9, No. 1. P. 63-75.

4. Carangelo, R. M., Solomon, P. R., Gerson, D. J. Application of TG-FT-i. r. to study hydrocarbon structure and kinetics // Fuel. 1987. Vol. 66, No. 7. P. 960967.

5. Zanier, A. Thermogravimetric Fourier transform infrared spectroscopy of hydrocarbon fuel residues // J. Therm. Anal. Cal. 1999. Vol. 56, No. 3. P. 1389_ 1396.

6. Strezov, V., Lucas, J. A., Evans, T. J., Strezov, L. Effect of heating rate on the thermal properties and devolatilisation of coal // J. Therm. Anal. Cal. 2004. Vol. 78, No. 2. P. 385-397.

7. Bassilakis, R., Carangelo, R. M., Wójtowiecz, M. A. TG-FTIR analysis of biomass pyrolysis // Fuel. 2001. Vol. 80, No. 12. P. 1765-1786.

8. Pitkänen, I., Huttunen, J., Halttunen, H., Vesterinen, R. Evolved gas analysis of some solid fuels by TG-FTIR // J. Therm. Anal. Cal. 1999. Vol. 56, No. 3. P. 1253-1259.

9. Lu,R., Purushotama, S., $\quad$ Yang, X., $\quad$ Hyatt, J., $\quad$ Pan, W-P., $\quad$ Riley, J. T., Lloyd, W. G. TG/FTIR/MS study of organic compounds evolved during the cofiring of coal and refuse-derived fuels // Fuel Process. Technol. 1999. Vol. 59, No. 1. P. 35-50.

10. Kaljuvee, T., Pelt, J., Radin, M. TG-FTIR study of gaseous compounds evolved at thermooxidation of oil shale // J. Therm. Anal. Cal. 2004. Vol. 78, No. 2. P. 399-414.

11. Kundel, H. A., Petaja, L. I. Thermogravimetric analysis of oil shale in air atmosphere // Oil Shale. 1985. Vol. 2, No. 4. P. 273-378 [in Russian].

12. Kök, M. V. Evaluation of Turkish oil shales - thermal analysis approach // Oil Shale. 2001. Vol. 18, No. 2. P. 131-138.

13. Cebulak, S., Gawęda, A., Langier-Kużniarowa, A. Oxyreactive thermal analysis of dispersed organic matter, kerogen and carbonization products - a tool for investigation of the heated rock masses // J. Therm. Anal. Cal. 1999. Vol. 56, No. 2. P. 917-924.

14. Paulik, F.,Paulik, J., Arnold, M. Kinetics and mechanism of the decomposition of pyrite under conventional and quasi-isothermal - quasi-isobaric thermoanalytical conditions // J. Therm. Anal. Cal. 1982. Vol. 25, No. 2. P. 313-325.

15. Jorgensen, F. R. A., Moyle, F. J. Phases formed during the thermal analysis of pyrite in air // J. Therm. Anal. 1982. Vol. 25, No. 2. P. 473-485.

16. Pelovski, $Y$., Petkova, $V$. Investigation on thermal decomposition of pyrite. Part I // J. Therm. Anal. Cal. 1999. Vol. 56, No. 1. P. 95-99. 
17. Lille, $\ddot{U}$. Current views on the origin of Estonian kukersite kerogen // Oil Shale. 2002. Vol. 19, No. 1. P. 3-18.

18. Kök, M. V., Pamir, M. R. ASTM kinetics of oil shale // J. Therm. Anal. Cal. 1998. Vol. 53, P. 567-575.

19. Kaljuvee, T., Kuusik, R. Emission of sulphur dioxide during thermal treatment of fossil fuels // J. Therm. Anal. Cal. 1999. Vol. 56, P, No. 3. 1243-1251.

20. Kaljuvee, T., Kuusik, R., Veiderma, M. Emission of sulphur dioxide by thermooxidation of Estonian oil shale and coal// Proc. Estonian Acad. Sci. Engng. 1998. Vol. 4, No. 3. P. 199-1208.

21. Kaljuvee, T., Kuusik, R., Radin, M., Bender, V. Carbon dioxide binding in the heterogeneous systems formed at combustion of oil shale. 4. Reactivity of ashes towards acid gases in the system fly ash-flue gases // Oil Shale. 2004. Vol. 21, No. 4. P. 13-26.

22. Xie, W., Liu, K., Pan, W-P., Riley, J. T. Interaction between emissions of $\mathrm{SO}_{2}$ and $\mathrm{HCl}$ in fluidized bed combustors // Fuel. 1999. Vol. 78, No. 12. P. 14251436.

23. Liu, K., Pan, W.-P., Riley, J. T. A study of chlorine behavior in a simulated fluidized bed combustion system // Fuel. 2000. Vol. 79, No. 9. P. 1115-1124.

24. Kuusik, R., Uibu, M., Kirsimäe, K. Characterization of oil shale ashes formed at industrial-scale CFBC boilers // Oil Shale. 2005. Vol. 22, No. 4 Special. P. 407420.

25. Partanen, J., Backman, P., Backman, R., Hupa, M. Absorption of $\mathrm{HCl}$ by limestone in hot flue gases. Part III: simultaneous absorption with $\mathrm{SO}_{2} / /$ Fuel. 2005. Vol. 84, No. 12-13. P. 1685-1694.

26. Ots, A., Pihu, T., Arro, H. Influence of sulphur dioxide and hydrogen chloride on properties of oil shale ash // Oil Shale. 2005. Vol. 22, No. 4 Special. P. 435444.

Presented by $\ddot{U}$. Rudi

Received August 28, 2006 